Available online at GSC Online Press Directory

GSC Biological and Pharmaceutical Sciences

e-ISSN: 2581-3250, CODEN (USA): GBPSC2

Journal homepage: https://www.gsconlinepress.com/journals/gscbps

(REVIEW ARTICLE)

\title{
Intoxication of the immature fruit of the ackee (Blighia sapida Koenig): Summary and development
}

Armand Kouassi Kakpo 1, ${ }^{*}$, Jacques Ahouassa ${ }^{1}$, Majella Chrysante Djohossou 1, Stanislas Djossou 1, Carolle Abiola Adjalla ${ }^{1}$, Claudia Aurelie Fagla ${ }^{1}$, Armel Thomas Elegbede ${ }^{1}$ and Moutawakilou Gomina ${ }^{2}$

${ }^{1}$ Pediatric service of the L'Abbraccio hospital of Sokponta, Glazoué, Republic of Benin.

${ }^{2}$ Unit for Training and Research in Biochemistry, Faculty of Medicine, University of Parakou, Parakou, Republic of Benin.

Publication history: Received on 27 September 2020; revised on 09 October 2020; accepted on 13 October 2020

Article DOI: https://doi.org/10.30574/gscbps.2020.13.1.0314

\begin{abstract}
Deaths linked to the consumption of plants are sometimes overlooked by health personnel in tropical environments. Parts of several plants are recognized as potentially toxic, including the fruit of the ackee.

This review paper aimed to synthesize data on the toxicity of the fruit of the ackee (Blighia sapida) and a brief overview on the measures of management of its acute intoxication.

This was a documentary and analytical study. We made an analysis/synthesis of the articles relating to the poisoning with the immature fruit of the ackee. The PubMed, AJOL and Google scholar databases were used.

The ackee is a plant native to West-Africa. Known by several names, lissètin in Fon in Benin, atsia in Evé in Togo, Finzan in Bambara in Mali, its aril contains lipids, proteins, carbohydrates, vitamins and trace elements. Hypoglycin is present in two forms A (2-methylene-cyclopropane-alanine) and B found in immature fruit, a very toxic compound which disrupts $\beta$-oxidation of fatty acids. Acute immature fruit poisoning, manifests as an acute hypoglycemic encephalopathy, gastrointestinal signs, hydro-electrolyte disturbances, metabolic acidosis and liver damage. The detection of urinary dicarboxylic acids is pathognomonic. Its treatment is symptomatic. A crude gastrointestinal and hepatic symptomatology characterizes chronic intoxication.
\end{abstract}

The ackee is a tree whose unripe fruit is of acute lethal toxicity. Treatment of acute intoxication is symptomatic.

Keywords: Ackee; Hypoglycin; Hypoglycemia; Urinary dicarboxylic acid; Poisoning.

\section{Introduction}

In the health context that is ours today, where any infant death must be a source of questioning, it becomes indisputable to wonder especially about the causes of those who are preventable. In addition to the causes which are classically incriminated (malaria, infections, etc.), there are many others, such as poisoning, especially in our rural areas, which kill children, outside of the radar of official statistics. In the Republic of Benin and as in the West African sub-region, several plants and fruits constitute an essential food resource [1,2]. Given their physicochemical properties, some constitute edible poisons that cause sometimes collective infant deaths $[3,4]$.

\footnotetext{
* Corresponding author: Armand Kouassi Kakpo

Pediatric service of the L'Abbraccio hospital of Sokponta,Glazoué, Republic of Benin.
} 
The ackee (Blighia sapida), is a tree whose fruit is highly prized by people in certain regions of Benin and the world [1]. The history of this plant relates to cases of death linked to the consumption of its fruit [4]. The first poisoning in Africa dates back to 1984 in Côte d'Ivoire, where mysteriously more than 70 deaths have been recorded [3, 5]. Investigations were needed later to clear the pesticides that were initially implicated. This fruit is said to contain a substance called hypoglycin, responsible for these deaths [6]. Several other cases of morbidity due to the consumption of the aril of Blighia sapida have been recorded worldwide [7]. Cases continue in our countries and deserve a closer look.

This synthesis aimed to take stock of the toxicity of the unripe fruit of the apple tree and the measures for managing its acute intoxication.

\section{Botanical aspects of Blighia sapida}

The ackee (Blighia sapida) is a medium-sized tree in the Sapindaceae family native to West Africa. The plant is said to have been introduced from Guinea to the Antilles, and to Jamaica in 1789, thanks to the slave trade [2, 5, 7, 8]. It is a species close to the "lychee" (Litchi chinensis). The ackee belongs to the reign of the plantae, to the division of magnoliaphyta and to the order of sapindales [2]. It is a beech tree, with prominent roots at the base of the trunk. Its foliage is massive, with a dense crown of spreading branches and carried by a robust trunk (Figure 1) [2, 7, 9]. The leaves are fifteen centimeters long. They are oval in shape, ending in a point; dark green in color and shiny at the upper base. The flowers are small, greenish or white in color. They measure less than a centimeter and are arranged in axillary clusters. The fruits, the size of a small pear, are pink to red in color, oval in shape, marked by three protruding ribs five to six centimeters long, sometimes longer (Figure 2). They contain one to three kernels the size of a nutmeg, black in color and shiny [9]. These stones are topped with a mass of ivory, white or cream-colored flesh, which has a nutty or avocado flavor. The black seed has a detestable taste (Figure 3) [7]. Blighia sapida is cultivated in tropical regions for its fruit which is widely consumed [10]. It is found in the countries of West Africa [2, 9, 11]. The different parts of the tree are used for several purposes: consumption, manufacture of soaps, pharmacopoeia $[1,12,13]$. He is very well known among the Malinkés, who call him finzan, from which comes the name which is sometimes given to him in French, "fisanier". Several other names are used to designate it: finsan fig, sweetbread, fricassee tree. It has various vernacular names (Table 1).

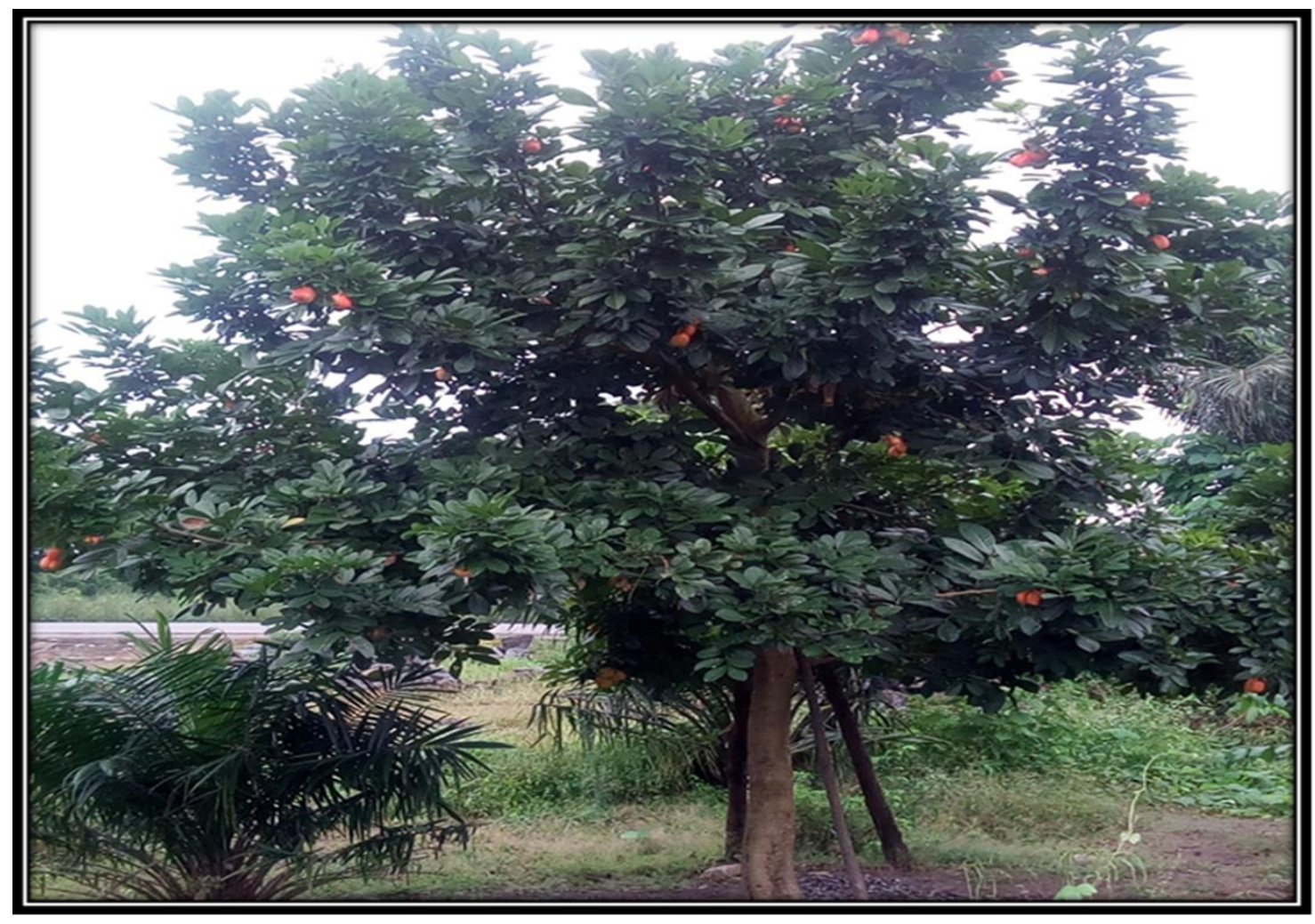

Figure 1 Blighia sapida shrub. (Photo Kakpo, 2017) 


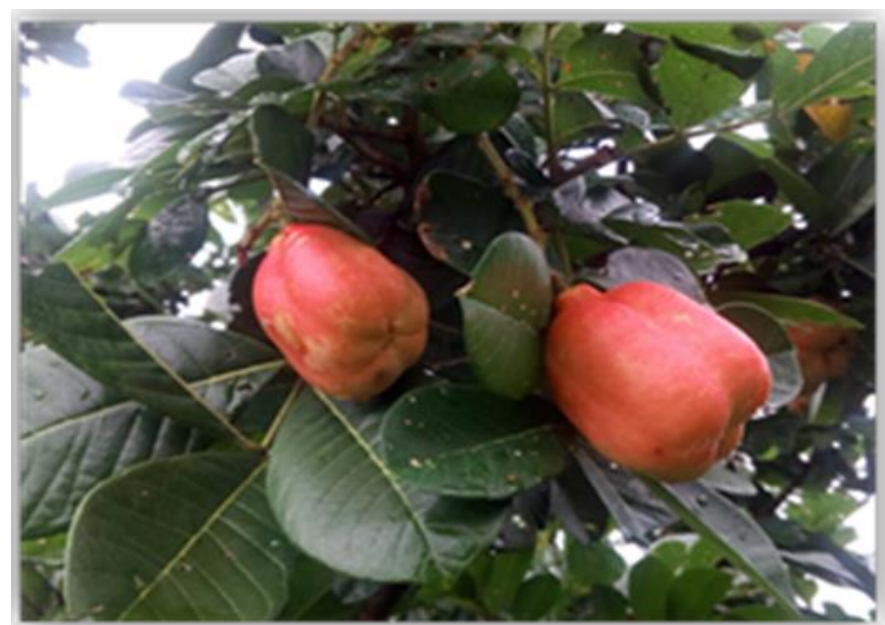

Figure 2 Not fully ripe fruit of Blighia sapida (Photo Kakpo, 2017)

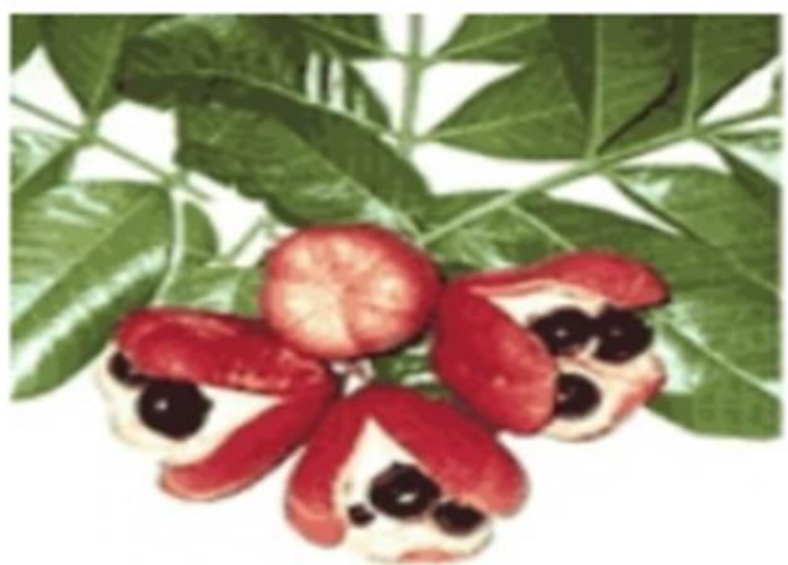

Figure 3 Fully ripe fruit of Blighia sapida [6]
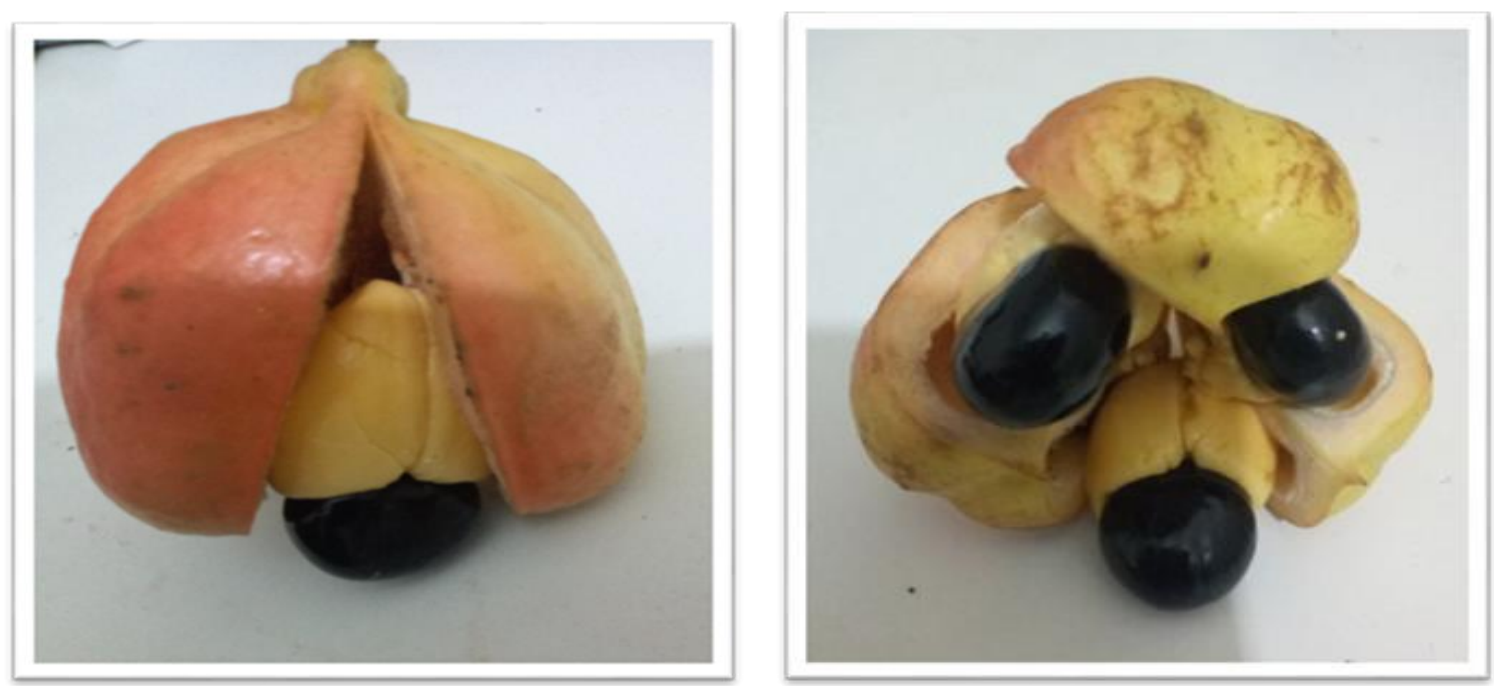

Figure 4 Fully ripe fruit of Blighia sapida. (Photo Kakpo, 2020) 
Table 1 Vernacular names of the ackee $[3,7]$

\begin{tabular}{|c|c|}
\hline Language & Vernacular name \\
\hline Tagwana & Kou, kohou, koum \\
\hline Djimini & Kokougo \\
\hline Baoulé & Каа \\
\hline Shien & Pagwé \\
\hline Attie & Baza \\
\hline Agni & Founzan, Foufoué, Baza \\
\hline Koulango & Songo \\
\hline Wobé & Goihien \\
\hline Bobo & Finsan \\
\hline Bambara & Finzan \\
\hline Haoussa & Fisa, Gwanja Kousa \\
\hline Ashanti & Achin, akyen, akye \\
\hline Twi & Ankye, akye, fufuo \\
\hline Fanti & Twitakwada \\
\hline Losso & Peso \\
\hline $\mathrm{Ga}$ & Hatschi, Ayigbeatia \\
\hline Basari & Bugpom \\
\hline Konkomba & Bugpob \\
\hline Malinké & Finzan \\
\hline Ebrié & Atuanbi \\
\hline Gouro & Tia \\
\hline Gagou & Sen \\
\hline Onitscha & Okwocha \\
\hline Yorouba & Ishin, ishinjife, ishinoka \\
\hline Bété & Newgouei \\
\hline Dioula & Finzan \\
\hline Mooré & Finzan \\
\hline Kabure & Peso \\
\hline Tschandjo & Peso \\
\hline Chumbulu & Kake \\
\hline Awuna & Adza, atsia \\
\hline Ewe & Adza, atsia \\
\hline Kuatchi & Keka \\
\hline Krobo & Kngatscho \\
\hline Ibo & Okpu \\
\hline Boki & Otusi-shet \\
\hline Kukuruku & Awai \\
\hline Jekri & Abikotor \\
\hline Ijaw & Ilipa \\
\hline Owerri & Okpuocha \\
\hline Nupe & Ila, ella \\
\hline Sobo & Ukperehren \\
\hline
\end{tabular}




\begin{tabular}{|l|c|}
\hline Fulani & Feso \\
\hline Adja & Atjan \\
\hline Ditamari, somba & Nufugodom, Moufodom \\
\hline Batombu & Diremou \\
\hline Natemba & Foulama \\
\hline Kabyé & Koosso \\
\hline Koto & GoléKpezo \\
\hline Moba & castanheiro da África \\
\hline Portuguese & Lissètin, Sissitin \\
\hline Fon & ackee, akee, akeeapple, achee, vegetable brain \\
\hline English & \\
\hline
\end{tabular}

\section{Phytochemical composition of Blighia sapida aril}

The main components of the aril of this fruit are lipids, which constitute more than $40 \%$, an oil level comparable to that of peanuts $[7,11,13]$. Proteins are also well represented with $20 \%$ while carbohydrates are low, representing less than $10 \%$ [14]. Aril is also rich in vitamin $\mathrm{C}$ and contains various other vitamins and minerals, mainly magnesium, sodium, calcium and phosphorus [7, 8, 10, 15, 16]. However, the aril contains, when the fruit is not ripe, a toxic compound, hypoglycin, which exists in two forms A (Figure 5) and B (Figure 6) [2, 8, 17]. It is an amino acid not included in the composition of proteins, isolated (as well as its gamma-glutamyl derivative, hypoglycin B) for the first time in 1955 by Hassal and Reyle [7]. Hypoglycin A is a water-soluble and thermostable compound, therefore not denatured by cooking. Fruit cooking water is more toxic than the fruit itself [7]. It is formed from an alanine residue linked to a methylenecyclopropane group and whose systematic name is 2-methylene-cyclopropane-alanine. Hypoglycin A is very high (1000 $\mathrm{ppm}$ ) in the unripe fruit, and its concentration decreases with ripening, until it drops below 100 ppm in the ripe fruit.

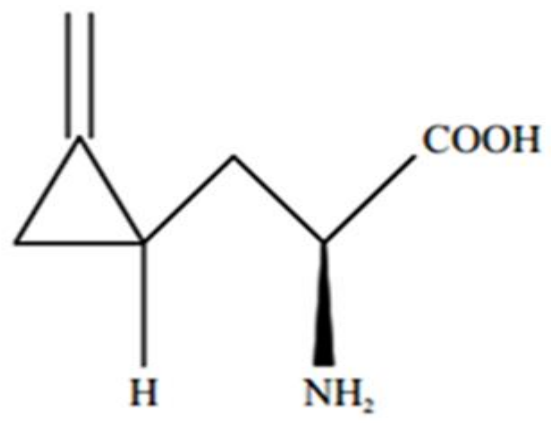

Figure 5 Structure of hypoglycin A $[17,18]$

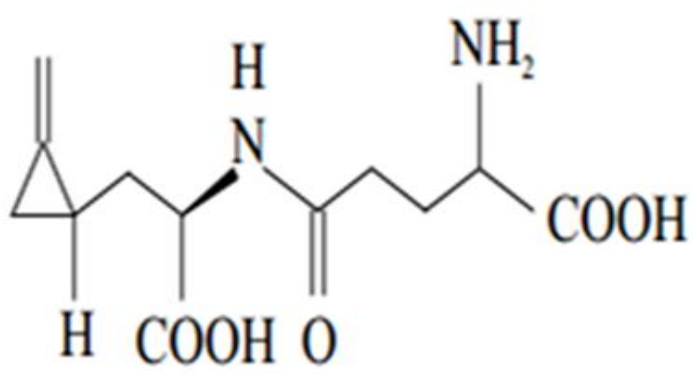

Figure 6 Structure of hypoglycin B $[17,18]$ 
Table 2 presents the quantified composition of the fruit seed of Blighia sapida.

Table 2 Phyto-chemical composition of the aril of the Blighia sapida fruit $[6,12]$

\begin{tabular}{|l|c|c|}
\hline & Quantity/100 g & Composition of 1 kg of dried aril \\
\hline Humidity (water) & $57,60 \mathrm{~g}$ & $6,84 \pm 1,13 \%$ \\
\hline Lipids & $18,78 \mathrm{~g}$ & $45,32 \pm 2,90 \%$ \\
\hline Carbohydrates & $9,55 \mathrm{~g}$ & $24,43 \pm 2,24 \%$ \\
\hline Protein & $8,75 \mathrm{~g}$ & $11,99 \pm 1,12 \%$ \\
\hline Fibers & $3,45 \mathrm{~g}$ & $3,21 \pm 0,34 \%$ \\
\hline Phosphate & $0,098 \mathrm{~g}$ & - \\
\hline Calcium & $0,083 \mathrm{~g}$ & $139,67 \pm 0,85(\mathrm{mg} / 100 \mathrm{~g})$ \\
\hline Ascorbic acid & $0,065 \mathrm{~g}$ & - \\
\hline Iron & $0,00552 \mathrm{~g}$ & $17,33 \pm 0,24(\mathrm{mg} / 100 \mathrm{~g})$ \\
\hline Niacin & $0,00374 \mathrm{~g}$ & - \\
\hline Riboflavin & $0,00018 \mathrm{~g}$ & - \\
\hline Thiamine & $0,00010 \mathrm{~g}$ & $215,33 \pm 1,03(\mathrm{mg} / 100 \mathrm{~g})$ \\
\hline Potassium & - & $53,17 \pm 1,03(\mathrm{mg} / 100 \mathrm{~g})$ \\
\hline Magnesium & - & $\pm 0(\mathrm{mg} / 100 \mathrm{~g})$ \\
\hline Sodium & - & $1503,3 \pm 1,89(\mathrm{mg} / 100 \mathrm{~g})$ \\
\hline Zinc & & \\
\hline
\end{tabular}

\section{Blighia sapida fruit poisoning}

\subsection{Pathophysiology}

Hypoglycin A is found in seeds and arils, while hypoglycin B is only found in seeds. This difference explains the fact that intoxications related to hypoglycin B are rare because the seed is not also consumed. Once ingested, hypoglycin A is metabolized in the liver to methylene-cyclopropyl-Acetyl-Coenzyme A (MCPA-CoA) [5]. This compound disrupts the catabolism of fatty acids in the mitochondria, preventing their oxidation (by inhibiting $\beta$-oxidation) and the resulting energy production [10]. MCPA-CoA binds in particular irreversibly to coenzyme A, carnitine and carnitine acyltransferases, reducing their bioavailability and consequently inhibiting $\beta$-oxidation of fatty acids [10]. The site where hypoglycine toxicity manifests has been identified as acyl-CoA dehydrogenases which catalyze the first stage of fatty acid oxidation [7]. The process of inhibiting acyl-CoA dehydrogenases by MCPA-CoA is initiated by a deprotonation, followed by a break in bond, leading to the formation of a conjugated carbanion. This carbanion binds covalently to the coenzyme Flavin Adenine Dinucleotide (FAD), which causes enzyme inactivation. The energy that the body needs can then only be produced from carbohydrates $[3,12]$. The hypoglycemic coma observed is therefore due to an abnormally exaggerated catabolism of carbohydrates since lipids are almost no longer a source of energy [5].

In addition to the decrease in blood sugar, hypoglycin causes a digestive syndrome made of uncontrollable vomiting, without diarrhea. It also causes convulsions, especially in young children. It is also a riboflavin or vitamin B2 antagonist. Consumption of high level of ackee fruit arils can cause vitamin deficiency, [5]. Figure 7 shows schematic summary of the different mechanisms that lead to this hypoglycemia. 


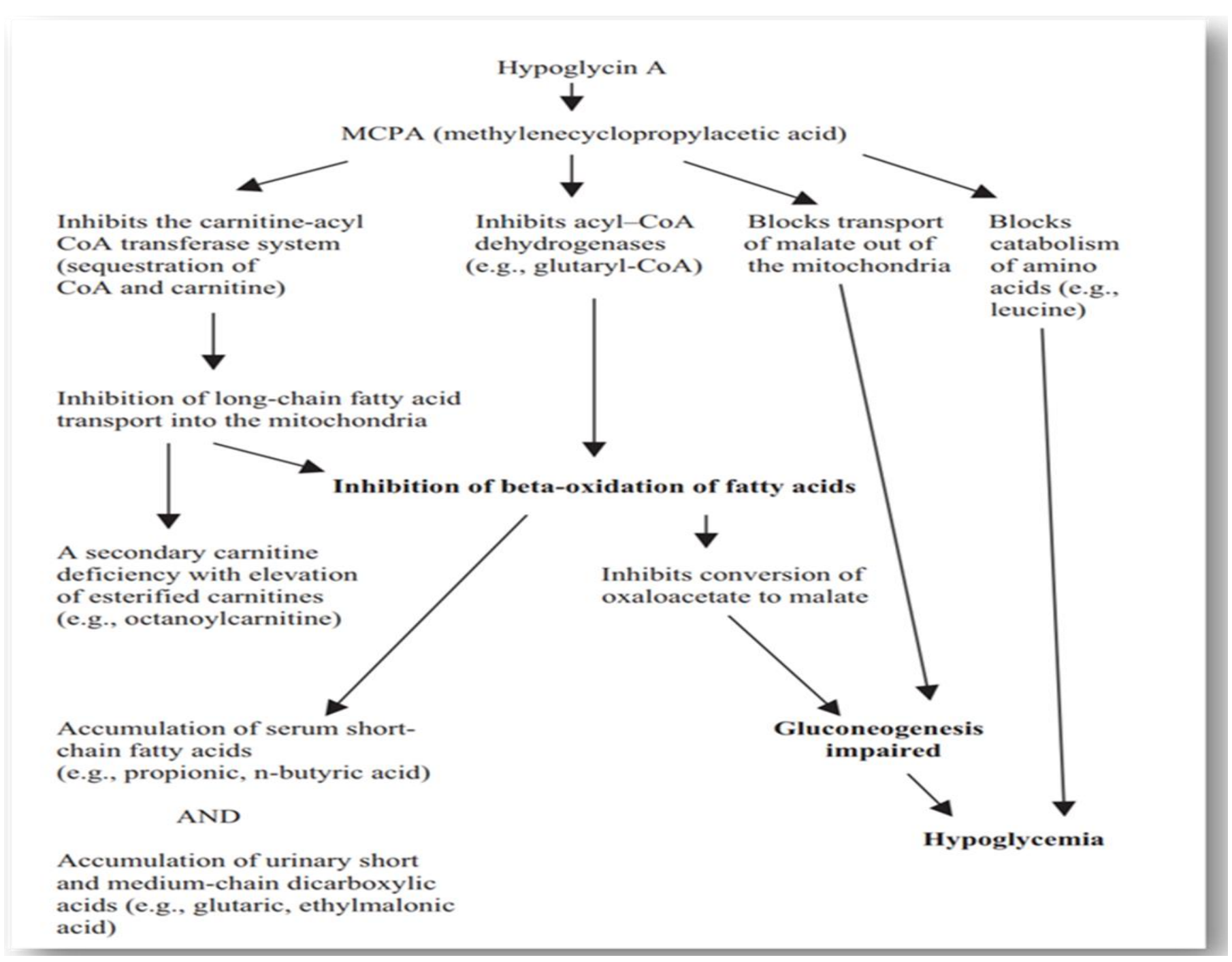

Figure 7 Metabolism and metabolic effects of the ackee fruit toxin, hypoglycin [19]

\subsection{Signs}

\subsubsection{Acute poisoning}

Still called emetising disease of Jamaica, acute hypoglycin A poisoning usually appears late in the meal. The affected subjects are very often young children who cannot identify the ripe fruits of the unripe. The weight/amount of toxin ratio also influences the severity of this disease in children. The clinical picture is that of an acute hypoglycemic often fatal encephalopathy. Depending on the extent of intoxication, the time for onset of symptoms may be delayed by several hours. Once started, the progression of symptoms is quite rapid and often of uncertain outcome. The clinical signs observed are diverse and sometimes inconsistent. There is often a deceptive lull before the fatal development. This period of calm must be known to the nursing staff so as not to lower their guard. Death occurs on average in 12 to 24 hours after the onset of signs [2, 3, 7]. The clinical signs observed are of three groups: general signs, gastrointestinal signs and neurological signs.

\section{General signs}

They are represented by impairment of the general condition with weakness, hypotonia, pallor and often intense thirst. Body temperature is normal or hypothermia can occur. Tachycardia and tachypnea are also observed in some cases [7].

\section{Gastrointestinal signs}

These signs boil down to persistent nausea and vomiting [20]. They are the first alarming symptoms of poisoning. They can be followed by a period of very deceptive lull. Cramps, abdominal pain and diarrhea are often absent [3]. 


\section{Neurological signs}

Neurological signs often start with headache. Above all, generalized convulsions are observed, sometimes preceded by clonic spasms or localized contractions of the limbs, then coma occurs.

From a biological point of view, the manifestations are of several orders [7, 20, 21]:

- A biological sign characteristic of intoxication with ackee fruit, hypoglycemia generally occurs a few hours after the onset of symptoms. Often very severe, it can reach values lower than $0.2 \mathrm{~g} / \mathrm{L}$;

- $\quad$ Metabolic acidosis following the accumulation of dicarboxylic acids;

- $\quad$ A hydro-electrolyte imbalance, a consequence of intense vomiting;

- The accumulation of lipids following the inhibition of $\beta$-oxidation in the liver cells will cause hepatotoxicity, manifested by: an increase in total and conjugated bilirubin as well as alkaline phosphatases, a syndrome of hepatic cytolysis (increased aminotransferases);

- Excessive elimination of dicarboxylic acids in the urine is a pathognomonic sign of poisoning in the ackee fruit; in particular, ethylmalonic, glutaric and adipic acids. Their detection and dosage makes it possible to establish the diagnosis of certainty;

- $\quad$ Some post-mortem liver biopsies revealed massive micro-vesicular steatosis, surrounded by macrovesicular steatosis affecting more than $90 \%$ of hepatocytes, without necrosis or associated inflammatory lesions. Cases of fulminant hepatitis have been described as linked to the consumption of the ackee fruit [22]

\subsubsection{Chronic poisoning}

Chronic poisoning by the ackee fruit is poorly documented. The literature mentions the possibility of cholestatic jaundice, observed following the repeated consumption of the ackee fruit. It is clinically characterized by pruritus, intermittent diarrhea, and localized abdominal pain in the hepatic region [23]. Liver tests show increased levels of total and conjugated bilirubin, alkaline phosphatases, and aminotransferases [14]. At liver biopsy, central lobular necrosis is observed [23]. A typical equine myopathy, a relatively rare disease touching horses consuming the seeds or seedlings of some maples, is known to be caused by hypoglycin A [21].

\subsection{Supported}

It often comes down to symptomatic treatment, depending on the clinical and biological manifestations observed. This care begins at the place of intoxication and must continue in a hospital environment.

\subsubsection{First steps at the scene of intoxication}

If the poisoning is recent and the patient is still conscious, he should be vomited immediately. This gesture can reduce the digestive absorption of the toxic and therefore limit its effects. It should be given to bite into pieces of sugar or to drink any glucose-containing substance to prevent hypoglycemia.

The transfer of unconscious patients must be done urgently and in a lateral safety position. The circumstances of discovery (notion of ingestion of unripe ackee fruit or the presence of unripe ackee fruit in or near the family concession) are very important for diagnosis and management.

\subsubsection{In a hospital environment}

Symptomatic treatment must be implemented upon admission to the hospital. It consists of taking charge of hypoglycemia, convulsions, hydro-electrolyte imbalances and possible coma.

\section{Hypoglycemia}

The correction of hypoglycemia is the first emergency of this therapy. It is done by the infusion of glucose serum (SG): $1 \mathrm{cc} / \mathrm{kg}$ of SG $30 \%$ or 3 to $5 \mathrm{cc} / \mathrm{kg}$ of SG $10 \%$ [7, 21,24-28]. Glucagon can be used from 0.5 to $1 \mathrm{mg}$ intramuscularly or subcutaneously. A relay to the $10 \%$ glucose serum in vein guard or an oral intake of slow sugar depending on the patient's condition must be systematic. Other authors suggest the use of cortisone [3]. When the venous route is impossible, a glucose solution must be provided by oral route or by a nasogastric tube. The response to treatment should be checked after 30 minutes. Highly concentrated solutions should be avoided as much as possible as they can lead to a state of hyper-osmolarity as well as reaction hypoglycemia in reaction to an increased secretion of insulin.

The glucose intake usually required to maintain acceptable blood sugar is 3 to $5 \mathrm{mg} / \mathrm{kg} / \mathrm{min}[7,24-28]$. 


\section{Convulsions}

Intravenous or intra-rectal administration of diazepam at a dose of $0.5 \mathrm{mg} / \mathrm{kg}$ allows the convulsions to subside, possibly repeated after half an hour if the attacks do not subside. If convulsions persist, the use of phenobarbital and then clonazepam (RIVOTRIL@) is indicated [7, 24-28].

\section{Maintenance of vital functions}

Clearance of the airways, ventilation, vascular filling, oxygenation and if necessary intubation to provide assisted ventilation are measures to be taken. These gestures are very important and are done according to the child's weight and age [24-28].

\section{Gastric lavage}

Gastric lavage is never the emergency for which priority should be given, since it is an evacuating treatment aimed at reducing the digestive absorption of the toxic. In all cases, vital failures must be corrected before practicing gastric lavage. The earliness and effectiveness of initial symptomatic treatment are more important than gastric lavage.

Gastric lavage requires certain conditions, in particular the good mastery of the technique by the nursing staff, the commitment or not of the vital prognosis, the duration of the ingestion which must not exceed three hours and the absence of ingestion of corrosive substances or derivatives of the associated oil. Make sure that a vacuum cleaner is available in case the child vomits. From a practical point of view, put the child on the left side, head down; measure the length of the probe to be inserted. The introduction of the probe is done by mouth. You just have to make sure it's in the stomach. The actual washing is carried out with saline serum at the rate of $10 \mathrm{cc} / \mathrm{kg}$ which is sent by the probe and which is removed immediately. The volume of liquid discharged should be approximately equal to that administered. Washing is stopped as soon as the liquid without gastric residue is obtained [24].

\section{Care-nursing}

They boil down to the prevention of bedsores, phlebitis and the administration of eye drops.

\section{Monitoring sheet}

It must include the following points: general information concerning the patient, vital signs (indicated by the score obtained on the coma scale or degree of consciousness, temperature, respiratory rate, pulse and weight), water balance, presence of clinical signs, presence of signs of complication, results of examinations, treatments administered, new signs or new complications.

\section{Conclusion}

The ackee is a tree whose unripe fruit is deadly toxic. Hypoglycin, a non-standard amino acid found abundantly in its unripe fruit, is responsible for the main manifestations of acute intoxication, by blocking the fatty acid oxidation. The dangerous nature of its immature fruit is not known. The management of acute intoxication is essentially focused on the correction of hypoglycemia and the maintenance of vital functions.

\section{Compliance with ethical standards}

\section{Acknowledgments}

We say our sincere thanks to all the staff of the Sokponta L'Abbraccio hospital for their daily sacrifice and to its promoters for the love they never stop showing to the populations in this an area of Benin.

Our sincere thanks to Dr Selim rashed, Associate clinical professor in pediatrics Montreal university, Assistant Professor in Tropical Diseases, McGill University, for your contribution to this article and for all that you do in medicine in Benin and Africa. 


\section{Disclosure of conflict of interest}

No conflict financial authors declared

\section{References}

[1] Ekue RM, Assogbadjo AE, Mensah GA, Codjia JT. Overview of the ecological distribution and the traditional agroforestry system around the ackee (Blighia sapida) in the Sudanese environment in North Benin. Benin Agronomic Research Bulletin. 2004; 44: 34-44.

[2] Aubry P. Poisoning by toxic plants in tropical and inter-tropical zones. Medicine tropical. 2012; 1-11.

[3] Moya IP. Cases of fatal poisoning by the aril of the fruit of Blighia sapida koenig (sapindaceae) in Côte d'Ivoire. Ethnomedicine Bulletin. 1985; 33: 67-71.

[4] Camille SB, Donna AM. Structural characterization of hypoglycin B, a diastereomeric dipeptide from the ackee fruit (Blighia sapida Koenig) by NMR experiments. Magnetic resonance chemistry. 2009; 47(11): 1004-6

[5] Moyal P. General information: natural products can be toxic, case of Cote d'Ivoire. Phytoma, defense of cultures. 1986; 383: 6.

[6] Atolani 0, Olatunji GA, Fabiyi OA. Blighia sapida; the plant and its hypoglycinsan overview. Journal of Scientific Research. 2009; 2 (39): 15-25.

[7] Valea I. Effect of methylene blue on acute poisoning by immature fruit of the strawberry tree (Blighia sapida, sapindaceae): experimental study in mice. Thesis in pharmacology. 2002; 78.

[8] Ouattara H, Meite A, Kouame P, Kati-Coulibaly S. Impact of Blighia sapida aril powder level in diet on the growth and the well-being of albino wistar rats. African Journal of Food Science. 2016; 10(9): 161-71.

[9] Orwa C, Mutua A, Kindt R, Jamnadass R, Anthony S. Agroforestree Database: a tree reference and selection guide version 4.0.2009. Juillet 2018.

[10] Ouattara H, Meite A, Amonkan KA, Kouame KG, Kati-Coulibaly S. Aril of Blighia sapida (K. Koenig, 1778): nutritional potential, toxic and deficient effects linked to its consumption, depending on the harvest stage and the degree of consumption. Int J Biol Chem. Sci. 2011; 5 (1): 392-401.

[11] Aloko S, Azubuike CP, Coke AB. Physicochemical properties and lubricant potentials of Blighia sapida Sapindaceaeae seed oil in solid dosage formulations. Tropical Journal of Pharmaceutical Research. 2017; 16 (2): 305-11.

[12] Ouattara H, Niamké B, Dally T, Kati-Coulibaly S. Nutritional composition studies of sun dried Blighia sapida (k. koenig) aril from Côte d'Ivoire. Journal of Applied Biosciences. 2010; 32: 1989 - 94.

[13] Dossou MK, Codjia JT, Biaou G. Uses, functions and perceptions of the resource species Blighia sapida (ackee or false mahogany) in north-western Benin. Benin Agronomic Research Bulletin. 2004; 45: 17-28.

[14] Azor AA, Abiodun AA, Kolade JJ, Afolabi T, Adesina AO. Haematolo-gical and hepatic indices of cockerels fed treated dietary Blighia sapida seeds. Biokemistri. 2012; 24(2): 72-6.

[15] Dossou VM, Agbenorhevi JK, Combey S, Afi-Koryoe S. Ackee (Blighia sapida) Fruit Arils: Nutritional, Phytochemicals and Antioxidant Properties. International Journal of Nutrition and Food Sciences. 2014; 3(6): 534-7.

[16] Dossou V, Agbenorhevi J, Alemawor F, Oduro I. Physicochemical and functional properties of full fatand defatted Ackee (Blighia sapida) Aril Flours. American Journal of Food Science and Technology. 2014; 2 (6): $187-91$.

[17] Gaillard Y, Carliera J, Mazoyer MC, Guittonc FJ, Fanton L. Fatal intoxication due to ackee (Blighia sapida) in Suriname and French Guyana. GC-MS detection and quantification of hypoglycin-A. Forensic Science International. 2011; 206: 103-7.

[18] Grande-Tovar CD, Delgado-Ospina J, Puerta LF, Rodríguez GC, Sacchetti G, Paparella A, Chaves-López C. Bioactive micro-constituents of ackee arilli (Blighia sapida K.D.Koenig). An Acad Bras Cienc 91. 2019; 91(3): 1-15. e20180140. 
[19] Joskow R, Belson M, Vesper H, Backer L, Rubin C. Ackee Fruit Poisoning: An Outbreak Investigation in Haiti 20002001, and Review of the Literature, Clinical Toxicology. 2006; 44(3): 267-73.

[20] Anderson-Foster NE, Adebayo AS, Justiz-Smith N. Physico-chemical properties of Blighia sapida (ackee) oil extract and its potential application as emulsion base. African Journal of Pharmacy and Pharmacology. 2012; 6(3): 200-10.

[21] Gillman JH, Hegeman AD, Sharp RG. Clarifying the role of maples in atypical 289 myopathy. Equine Veterinary Journal. 2014; 46: 135-6.

[22] Dianne E. G, Irini Scordi-Bello, Matthew S, Sander F, Jonathan Y, Maria Isabel F, Swan N. T. Fulminant hepatic failure attributed to ackee Fruit Ingestion in a Patient with Sickle Cell Trait. Corporation Case Reports in Transplantation. 2012; 1-4

[23] Larson J, Vender R, Camuto P. Cholestatic jaunice due to ackee fruit poisoning. American Journal of Gastroenterology. 1994; 89(9): 1577-8.

[24] Bellaïche M. Pham A. Pédiatrie. 10e Ed. Paris: Editions Vernazobres-Grego. 2017.

[25] Bourrous M, Hindi M. Guide pratique des principales urgences pédiatriques. Thèse de doctorat en médecine. Faculté de médecine et de pharmacie de l’Université Cadi Ayyad, Maroc. 2019.

[26] WHO. Pediatric hospital care: management of common ailments in small hospitals. WHO Publishing: 2007.

[27] Turgeon J, Hervouet-Zeiber C, Overtchkine P, Bernard Bonnin A. Gautthier M. Dictionary of Pediatrics, Weber. 3e Ed. Canada: Edition Chenelière. 2015.

[28] Médecins sans frontières. Clinical and therapeutic guide. Edition. 2016; 363 